\title{
PERBANYAKAN TANAMAN HIAS AIR Bacopa australis SECARA IN VITRO PADA BERBAGAI FORMULASI HORMON MEDIA PERTUMBUHAN
}

\author{
Rossa Yunita*\#, Endang Gati Lestari ${ }^{*}$, Mastur ${ }^{*}$, dan Media Fitri Isma Nugraha**) \\ *) Balai Besar Penelitian dan Pengembangan Bioteknologi dan Sumberdaya Genetik Pertanian \\ Jl. Tentara Pelajar No. 3A, Bogor 16111 \\ *) Balai Riset Budidaya Ikan Hias \\ Jl. Perikanan No. 13, Pancoran Mas, Depok 16436
}

(Naskah diterima: 22 Februari 2018; Revisi final: 10 September 2018; Disetujui publikasi: 11 September 2018)

\begin{abstract}
ABSTRAK
Suksesnya pembentukan indukan (mother plant) tanaman hias air Bacopa australis pada penelitian sebelumnya, mendorong perbanyakan tanaman dengan menggunakan teknik kultur in vitro secara massal untuk menghasilkan bibit Bacopa australis dalam jumlah yang banyak dan relatif lebih cepat. Tujuan penelitian adalah mendapatkan formulasi media yang tepat untuk induksi tunas, multiplikasi tunas, dan induksi perakaran yang cepat secara in vitro dari Bacopa australis. Penelitian ini terdiri atas tiga tahapan kegiatan, yaitu induksi tunas, multiplikasi tunas, dan induksi akar. Hasil penelitian menunjukkan formulasi media yang terbaik induksi tunas Bacopa australis secara in vitro adalah MS + BA 0,3 mg/L. Formulasi media yang optimal untuk multiplikasi tunas adalah $\mathrm{MS}+\mathrm{BA} 0,5 \mathrm{mg} / \mathrm{L}+$ Thidiazuron $0,1 \mathrm{mg} / \mathrm{L}$ dan induksi perakaran adalah MS + IBA 0,5 mg/L.
\end{abstract}

\begin{abstract}
KATA KUNCl: Bacopa australis; benzil adenin; indole butyric acid; perbanyakan tanaman; thidiazuron
ABSTRACT: In vitro propagation of ornamental aquatic plants Bacopa australis in various growth hormon medium. By: Rossa Yunita, Endang Gati Lestari, Mastur, and Media Fitri Isma Nugraha

The successful establishment of mother plant Bacopa australis in the previously related research opens an opportunity to produce relatively fast and in large quantities Bacopa australis seeds using in vitro mass culture techniques. The objective of the study was to determine suitable formulated media for shoot induction, shoot multiplication, and root induction of Bacopa australis. This study consisted of three research stages, namely shoot induction, shoot multiplication, and root induction. The results showed that the best formulated media for in vitro Bacopa australis shoot induction was MS + BA $0.3 \mathrm{mg} / \mathrm{L}$. The optimal formulated media for shoot multiplication was MS + BA $0.5 \mathrm{mg} / \mathrm{L}+$ Thidiazuron $0.1 \mathrm{mg} / \mathrm{L}$ and for root induction was MS + IBA $0.5 \mathrm{mg} / \mathrm{L}$.
\end{abstract}

KEYWORDS: Bacopa australis; benzil adenin; indole butyric acid; plant propagation; thidiazuron

\section{PENDAHULUAN}

Sejak era 1980 tanaman hias air sudah dikenal di Indonesia untuk kalangan terbatas. Budidaya komoditas ini mulai popular sekitar tahun 2000 akan tetapi teknologi budidayanya masih secara konvensional. Pada tahun 2004 Indonesia mampu melakukan ekspor tanaman hias air ke-28 negara, akan tetapi karena tingginya permintaan dan beragam jenis tanaman hias, sehingga tidak mampu memenuhi pasar luar negeri,

\footnotetext{
\# Korespondensi: Balai Besar Penelitian dan Pengembangan Bioteknologi dan Sumberdaya Genetik Pertanian JI. Tentara Pelajar No. 3A, Bogor 16111, Indonesia. Tel.: + 622518337975

E-mail: media.nugraha@ kkp.go.id
}

mengakibatkan terjadimya penurunan terhadap nilai ekspor komoditas ini (Bank Indonesia, 2008).

Bacopa australis merupakan jenis gulma air yang banyak diminati oleh konsumen baik di dalam maupun luar negeri. Bacopa australis awalnya ditemukan di Brasil Selatan. Bacopa australis mudah tumbuh di akuarium dan pada kondisi tertentu dapat merayap di bagian dasar akuarium membentuk bantalan hijau yang elegan dan dekoratif.

Nugraha et al. (2017) telah melakukan pembentukan tanaman indukan aseptik (mother plant) untuk tanaman air Bacopa australis secara in-vitro. Mother plant yang sudah terbentuk ini akan diperbanyak secara massal; oleh karena itu, perlu dicari 
suatu formulasi zat pengatur tumbuh yang dapat menghasilkan bibit yang seragam, cepat dalam jumlah besar.

Teknologi yang dapat digunakan untuk penyediaan bibit dalam jumlah besar dan waktu relatif lebih singkat adalah teknik kultur in vitro. Teknologi yang sama telah berhasil untuk perbanyakan Artemisia annua (Yunita \& Lestari, 2008) Baccopa monnieri (Dharishini et al., 2014), Rauwolfia serpentina L. (Yunita \& Lestari, 2011).

Perbanyakan tanaman secara in vitro melalui jalur organogenesis mampu menghasilkan bibit tanaman yang seragam baik dari segi morfologi maupun genetik (Yunita et al., 2012). Teknologi ini mampu menghasilkan bibit dalam jumlah yang relatif besar pada areal yang tidak begitu luas dan tidak dibatasi oleh faktor iklim. Modifikasi media tanam pada beberapa unsur, teknik ini dapat menghasilkan bibit yang bebas patogen (jamur, virus, bakteri).

Keberhasilan teknologi kultur jaringan, dipengaruhi oleh sejumlah faktor yang kompleks, di antaranya adalah nutrisi dan senyawa organik berupa zat pengatur tumbuh. Kandungan hara makro dan mikro sangat dibutuhkan untuk terjadinya proses morfogenesis. Perbanyakan melalui jalur organogenesis, pada tahap pembentukan tunas penambahan sitokinin tanpa auksin akan memacu penggandaan tunas karena penambahan sitokinin mampu menghilangkan dormansi tunas apikal (Zulkarnain, 2011; Hartati et al., 2014).

Benzil adenin (BA) merupakan salah satu jenis sitokinin yang umum digunakan untuk induksi tunas karena mampu menginduksi terjadinya pembelahan sel, pembentukan organ seperti pucuk (Hartati et al., 2014). Thidiazuron merupakan senyawa difenil urea yang memiliki sifat hampir sama dengan sitokinin. Thidiazuron dapat menginduksi multiplikasi tunas lebih cepat daripada sitokinin jenis lain (Khawar et al., 2003). Guo et al., (2011) menjelaskan bahwa thidiazuron berperan menstimulasi produksi sitokinin endogen sel. Pada pengunaannya umumnya dikombinasikan dengan BA untuk meningkatkan multiplikasi tunas. Auksin Indole Butyric Acid (IBA) merupakan hormon potensial yang banyak direspons oleh berbagai tanaman untuk indusi akar (Santos et al., 2003) karena IBA mampu menstimulasi munculnya tunas akar.

Suksesnya pembentukan mother plant Bacopa australis oleh Nugraha et al. (2017) maka penelitian ini dirasa perlu dilanjutkan dengan tujuan untuk mendapatkan formulasi zat pengatur tumbuh yang tepat untuk induksi tunas, multiplikasi tunas, dan induksi perakaran secara in vitro dari Bacopa australis.

\section{BAHAN DAN METODE}

Penelitian dilakukan pada bulan Januari hingga Juni 2017 di laboratorium Biologi Sel dan Jaringan, Balai Besar Penelitian dan Pengembangan Bioteknologi dan Sumberdaya Genetik Pertanian (BB-Biogen), Bogor. Bahan tanaman yang digunakan adalah biakan aseptik dari mother plant (induk tanaman dalam in vitro) Bacopa australis (L.) Koleksi hasil kerja sama Balai Riset Budidaya Ikan Hias dan BB-Biogen. Biakan in vitro Bacopa australis (L.) disubkultur pada media dasar MS (Murashige \& Skoog, 1962). Media MS dibuat sesuai dosis formula dari Murashige \& Skoog (1962), yang diperkaya dengan zat pengatur tumbuh sesuai perlakuan yang diberikan dan dilengkapi dengan sukrosa 3\% (w/v), serta dibuat padat dengan menambahkan agar 0,2\% (phytagel/Gelrate). Kemasaman media dibuat 5,8 dengan menambahkan $1 \mathrm{~N} \mathrm{NaOH}$ atau $1 \mathrm{~N} \mathrm{HCl}$. Media kultur dimasukkan dalam wadah botol kaca dan di-autoclave pada suhu $121^{\circ} \mathrm{C}$ selama 15 menit. Setelah di-autoclave media kultur diletakkan pada ruang kultur pada suhu $25^{\circ} \mathrm{C}$ hingga masa tanam dilakukan. Setelah tiga hari eksplan di tanaman dengan ukuran $1 \mathrm{~cm}$ kemudian disimpan di luar penyimpanan dengan intensitas penyinaran sebesar 1.000-2.000 lux selama 16 jam/hari. Setelah biakan berumur dua bulan, setinggi $\pm 5 \mathrm{~cm}$ dan menghasilkan daun yang memiliki ukuran yang memadai sebagai eksplan. Eksplan yang digunakan adalah batang yang memiliki dua mata tunas dengan panjang $\pm 0,7 \mathrm{~cm}$.

Penelitian ini terdiri atas tiga tahapan kegiatan yaitu: (1) induksi tunas, (2) multiplikasi tunas, (3) induksi perakaran.

\section{Induksi Tunas}

Pada kegiatan induksi tunas ini, eksplan dengan ukuran $1 \mathrm{~cm}$, yang digunakan berupa ruas batang dari hasil indukan aseptik. Media yang digunakan adalah media dasar MS yang diperkaya dengan zat pengatur tumbuh (ZPT) yaitu BA. Rancangan acak lengkap (RAL) digunakan dalam penelitian ini dengan perlakuan pada konsentrasi BA yaitu 0,$0 ; 0,3 ; 0,5 ; 0,7 \mathrm{mg} / \mathrm{L}$. Masing perlakuan terdiri atas 10 ulangan. Pengamatan dilakukan setelah tujuh hari setelah tanaman, dan pengamatan dilakukan pada seluruh eksplan tanaman yang dikultur. Peubah yang diamati adalah, jumlah tunas (banyaknya tunas yang terbentuk) dan jumlah daun yang terbentuk. Data yang diperoleh dianalisis secara 
stasistik dan apabila terdapat pengaruh yang nyata dari perlakuan terhadap peubah yang diamati, kemudian dilakukan uji lanjut Duncan pada taraf kepercayaan 95\%

\section{Multiplikasi Tunas}

Tunas yang telah berukuran $2 \mathrm{~cm}$, yang dihasilkan pada kegiatan induksi tunas dipindahkan ke media multiplikasi. Media untuk multiplikasi adalah media dasar MS yang diperkaya dengan BA dan thidiazuron. Dalam satu botol media multiplikasi tunas terdapat tiga tanaman. Rancangan yang digunakan pada penelitian ini adalah rancangan acak lengkap faktorial. Faktor yang pertama adalah konsentrasi BA yaitu 0,0 ; 0,$5 ; 1,0 ;$ dan $1,5 \mathrm{mg} / \mathrm{L}$ dan faktor yang kedua yaitu konsentrasi thidiazuron yaitu 0,$0 ; 0,1,0,3$; dan 0,5 $\mathrm{mg} / \mathrm{L}$. Masing-masing perlakuan terdiri atas 10 ulangan. Pengamatan dilakukan pada umur satu minggu setelah tanaman pada seluruh eksplan tanaman. Peubah yang diamati meliputi jumlah tunas dan jumlah daun. Apabila terdapat pengaruh yang nyata dari perlakuan yang dianalisis secara statistik terhadap peubah yang diamati, maka dilakukan uji lanjut Duncan pada taraf kepercayaan $95 \%$

\section{Induksi Perakaran}

Tunas dari perlakuan multiplikasi tunas yang telah tumbuh $\pm 5 \mathrm{~cm}$, dipindahkan pada media perakaran, dengan jumlah tiga eksplan per botol kultur. Perco baan induksi akar menggunakan media MS yang diperkaya dengan auksin IBA. Penelitian ini menggunakan rancangan acak lengkap dengan perlakuan konsentrasi IBA konsentrasi yaitu 0,$0 ; 0,5 ; 1,0$ mg/L. Masing-masing perlakuan terdiri atas 10 ulangan. Peubah yang diamati adalah jumlah akar dan panjang akar setelah berumur delapan minggu. Data dianalisis secara stasistik dan bila terdapat pengaruh yang nyata dari peubah yang diamati, kemudian dilakukan uji lanjut Duncan pada taraf kepercayaan $95 \%$

\section{HASIL DAN BAHASAN}

\section{Induksi Tunas}

Secara umum eksplan Bacopa australis mampu menghasilkan tunas akan tetapi jumlah yang dihasilkan bervariasi. Hasil analisis ANOVA menunjukkan bahawa perlakuan konsentrasi BA memberikan pengaruh yang berbeda nyata terhadap jumlah tunas maupun jumlah daun. Beberapa hasil penelitian menunjukkan umumnya tanaman Bacopa sp. diperbanyak secara in vitro menggunakan batang yang memiliki mata tunas sebagai eksplan (Vijayakumar et al., 2010; Pandiyan \& Selvaraj, 2012; Kapil \& Sharma, 2014).

Pemberian BA hingga 0,3 mg/L mampu menginduksi terbentuknya tunas paling banyak dan memberikan pengaruh yang berbeda nyata daripada perlakuan 0,0 ; 0,5; 0,7 mg/L (Gambar 1 dan 2). Selain jumlah tunas yang lebih banyak, perlakuan BA 0,3 mg/L menghasilkan rataan jumlah daun yang lebih banyak, serta berbeda nyata dari perlakuan lainnya. Hal yang sama ditunjukan dari hasil penelitian induksi tunas Artemisia annua; menunjukan bahwa media terbaik untuk menginduksi tunas adalah media yang mengandung BA (Yunita \& Lestari, 2008). Perlakuaan BA $0,3 \mathrm{mg} / \mathrm{L}$ juga menghasilkan jumlah daun yang mempunyai mata tunas pada ketiak daun yang lebih banyak dari perlakuan lainnya. Dalam perbanyakan tanaman secara in vitro hal ini sangat penting karena mata tunas yang berada pada ketiak daun dapat dimanfaatkan sebagai sumber eksplan baru.

Eksplan yang dikultur pada media tanpa BA menghasilkan jumlah rataan tunas yang paling rendah yaitu 1,1 dengan jumlah rataan daun 9,2 (Gambar 1). Eksplan yang dikulturkan pada media yang mengandung BA hingga konsentrasi tertentu mampu meningkatkan terbentuknya tunas dan daun. Hasil penelitian menunjukkan bahwa pemberian sitokinin terutama BA pada media sangat penting dalam induksi tunas secara in vitro pada berbagai jenis tanaman di antaranya Bacopa monnieri (L.) (Pandiyan \& Selvara, 2012; Kapil \& Sharma, 2014), Withania somnifera (Chandran et al., 2007), Sarcostemma brevistigm (Thomas \& Shankar, 2009).

Pada Gambar 1 juga dapat diamati bahwa pemberian BA lebih besar dari 0,5 mg/L akan menurunkan kemampuan eksplan membentuk tunas, di mana pada konsentrasi $0,5 \mathrm{mg} / \mathrm{L}$ jumlah rata-rata tunas yang terbentuk adalah 1,4 dengan jumlah rata-rata daun 9,4. Pada perlakuan BA 0,7 mg/L terjadi penurunan jumlah rata-rata tunas dan daun. Konsentrasi BA yang relatif tinggi pada media kultur akan menghambat pembentukan tunas dan daun pada eksplan Bacopa australis. Pemberian BA pada konsentrasi relatif tinggi akan menghambat pembentukan organ pada kultur. Aplikasi sitokinin pada konsentrasi tinggi dapat mengganggu penyerapan unsur hara, serta menghambat pertumbuhan eksplan (Karyanti, 2017). Respons zat pengatur tumbuh yang terekspresi tergantung pada kemampuan eksplan dalam menyerap dan menggunakan zat pengatur tumbuh endogen yang ada dan ZPT eksogen yang diserap dari media tumbuh (Tuhuteru et al., 2012).

\section{Multiplikasi Tunas}

Pada penelitian multiplikasi tunas, eksplan yang digunakan berasal dari kegiatan induksi tunas yang berasal dari perlakuan terbaik. Tunas yang disubkultur berukuran $\pm 1 \mathrm{~cm}$ dan memiliki dua nodus (buku batang). Hasil analisis ANOVA menunjukkan interaksi 


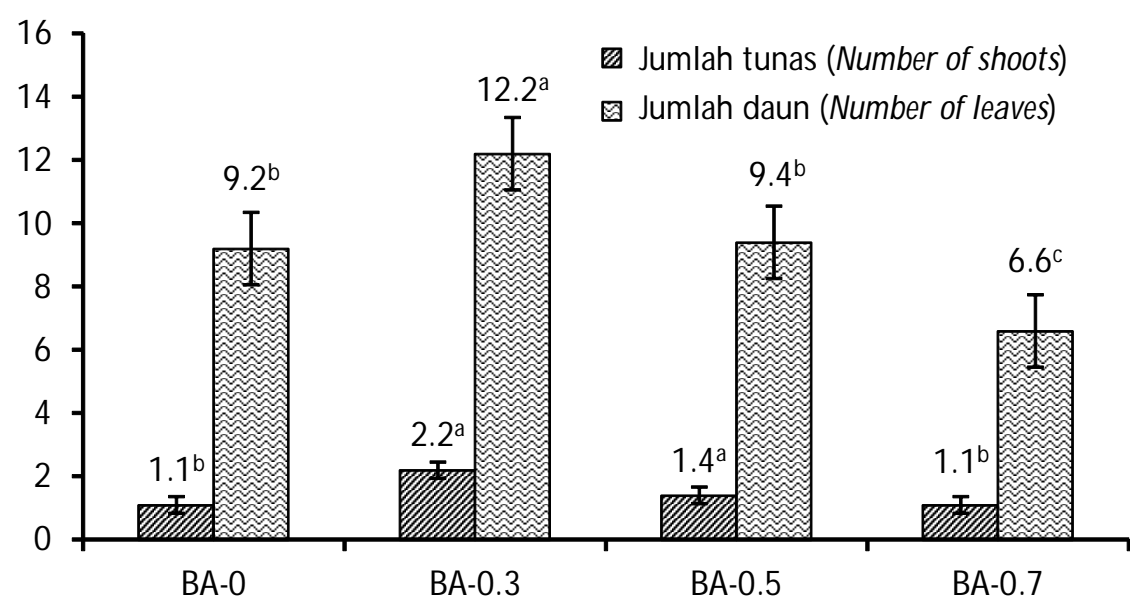

Keterangan: Angka yang diikuti oleh huruf sama pada baris dan kolom yang sama tidak berbeda nyata pada taraf $5 \%$ uji jarak berganda Duncan

Remarks: Values followed by the same letter in the same row and column are not significantly different at the $5 \%$ level, according to Duncan's multiple-range test

Gambar 1. Pengaruh konsentrasi BA terhadap jumlah tunas dan jumlah daun pada eksplan Bacopa australis.

Figure 1. Effect of BA concentration on shoot number and number of leaves on explant Bacopa australis.
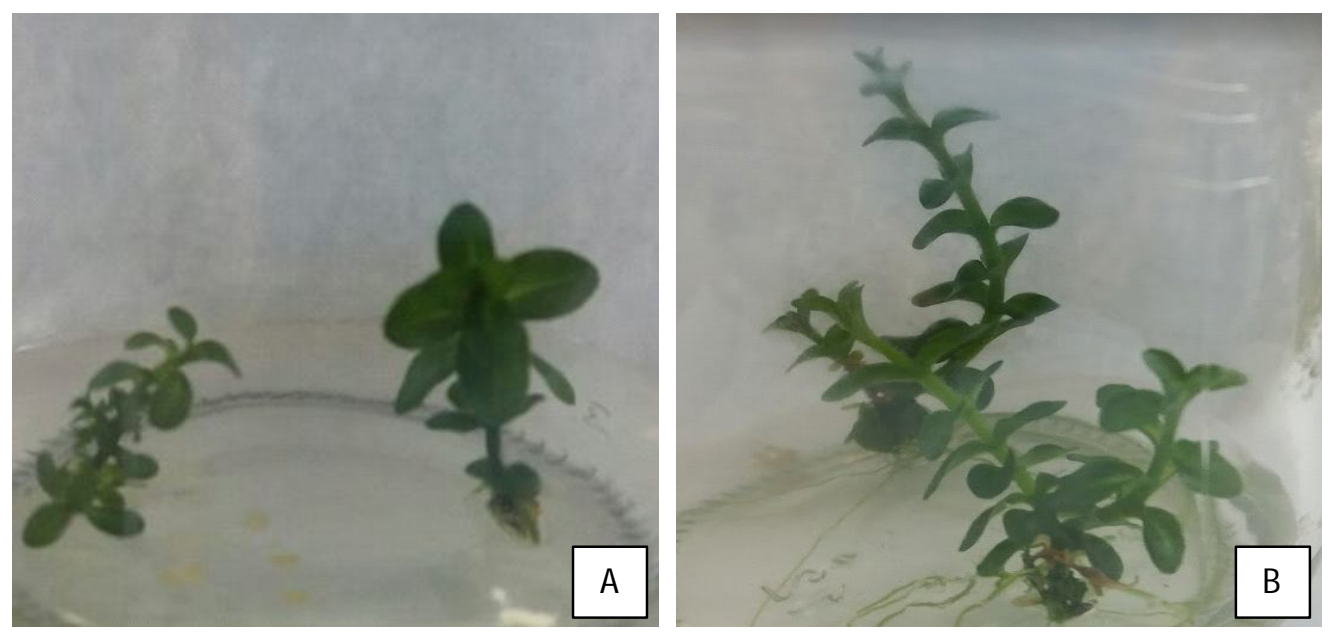

Gambar 2. Induksi tunas pada media MS (A); induksi tunas pada media MS + BA $0,3 \mathrm{mg} / \mathrm{L}(\mathrm{B})$.

Figure 2. Shoot induction on MS medium (A); on MS + BA $0.3 \mathrm{mg} / \mathrm{L}(\mathrm{B})$.

dari BA dan thidiazuron memberikan pengaruh yang nyata terhadap jumlah tunas maupun jumlah daun.

Pemberian thidiazuron tanpa kombinasi zat pengatur tumbuh lain mampu meningkatkan kemampuan tunas untuk bermultiplikasi. Penghitungan jumlah tunas dilakukan setiap satu minggu sekali pada seluruh eksplan yang dikultur. Peningkatan konsentrasi thidiazuron hingga 0,1 mg/L mampu meningkatkan jumlah tunas hingga rata-rata 3,5 tunas (Tabel 1 ) dan jumlah daun 36 (Tabel 2; Gambar 3A). Peningkatan thidiazuron menjadi $0,3 \mathrm{mg} / \mathrm{L}$ dan pada $0,5 \mathrm{mg} / \mathrm{L}$ cenderung akan menurunkan kemampuan eksplan membentuk tunas dan daun walaupun tidak berbeda nyata dengan perlakuan thidiazuron 0,1 mg/L. Keadaan yang sama juga terjadi pada beberapa jenis tanaman di antaranya Plumbago zeylanica, Rauwolfia serpentina L., di mana pemberian thidiazuron yang seimbang mampu menginduksi multiplikasi tunas. Hal ini karena thidiazuron memiliki kemampuan untuk menginduksi terjadinya proses pembelahan sel (Yunita \& Lestari, 2011; Syahid \& Kristina, 2008). 
Tabel 1. Pengaruh kombinasi BA dan thidiazuron terhadap rata-rata jumlah tunas eksplan Bacopa australis

Table 1. The influence of combination of BA and thidiazuron on the average number of shoot of explant Bacopa australis

\begin{tabular}{ccccc}
\hline $\begin{array}{c}\text { Konsentrasi BA } \\
\text { BA concentration } \\
(\mathbf{m g} / \mathbf{L})\end{array}$ & $\mathbf{5}$ & \multicolumn{4}{c}{$\begin{array}{c}\text { Konsentrasi thidiazuron } \\
\text { Thidiazuron concentration }(\mathbf{m g} / \mathbf{L})\end{array}$} \\
\cline { 2 - 5 } & $\mathbf{0}$ & $\mathbf{0 . 1}$ & $\mathbf{0 . 3}$ & $\mathbf{0 . 5}$ \\
\hline 0 & $1.3 \pm 0.48^{\mathrm{e}}$ & $3.5 \pm 0.84^{\mathrm{e}}$ & $2.7 \pm 0.94^{\mathrm{e}}$ & $2.2 \pm 1.14^{\mathrm{e}}$ \\
0.5 & $11.2 \pm 0.9^{\mathrm{d}}$ & $32.4 \pm 4.91^{\mathrm{a}}$ & $20.9 \pm 8.94^{\mathrm{c}}$ & $10.4 \pm 1.84^{\mathrm{d}}$ \\
1.0 & $4.0 \pm 0.82^{\mathrm{C}}$ & $24.3 \pm 7.95^{\mathrm{b}}$ & $12.2 \pm 2.53^{\mathrm{d}}$ & $1.1 \pm 0.56^{\mathrm{e}}$ \\
1.5 & $3.5 \pm 1.14^{\mathrm{e}}$ & $21.8 \pm 7.55^{\mathrm{bc}}$ & $9.8 \pm 2.20^{\mathrm{d}}$ & $1.0 \pm 0.67^{\mathrm{e}}$ \\
\hline
\end{tabular}

Keterangan: Angka yang diikuti oleh huruf sama pada baris dan kolom yang sama tidak berbeda nyata pada taraf $5 \%$ uji jarak berganda Duncan

Remarks: Values followed by the same letter in the same row and column are not significantly different at the $5 \%$ level, according to Duncan's multiplerange test

Tabel 2. Pengaruh kombinasi BA dan thidiazuron terhadap rata-rata jumlah daun eksplan Bacopa australis

Table 2. The influence of combination of $B A$ and thidiazuron on the average number of leaves of explant Bacopa australis

\begin{tabular}{ccccc}
\hline $\begin{array}{c}\text { Konsentrasi BA } \\
\text { BA concentration } \\
\text { (mg/L) }\end{array}$ & $\mathbf{5} \begin{array}{c}\text { Konsentrasi thidiazuron } \\
\text { Thidiazuron concentration (mg/L) }\end{array}$ \\
\cline { 2 - 5 } & $\mathbf{0}$ & $\mathbf{0 . 1}$ & $\mathbf{0 . 3}$ & $\mathbf{0 . 5}$ \\
\hline 0 & $7.3 \pm 3.13^{\mathrm{g}}$ & $36.0 \pm 7.15^{\mathrm{cd}}$ & $26.4 \pm 7.26^{\mathrm{de}}$ & $23.4 \pm 3.78^{\mathrm{ef}}$ \\
0.5 & $24.1 \pm 2.51^{\mathrm{ef}}$ & $137.6 \pm 14.3^{\mathrm{a}}$ & $40.1 \pm 17.6^{\mathrm{c}}$ & $29.2 \pm 13.37^{\mathrm{de}}$ \\
1.0 & $38.9 \pm 8.97^{\mathrm{c}}$ & $49.4 \pm 15.7^{\mathrm{b}}$ & $24.0 \pm 6.49^{\mathrm{ef}}$ & $16.0 \pm 10.33^{\mathrm{fg}}$ \\
1.5 & $35.20 \pm 6.91^{\mathrm{cd}}$ & $43.7 \pm 16.6^{\mathrm{bc}}$ & $20.1 \pm 7.65^{\mathrm{ef}}$ & $14.2 \pm 10.86^{\mathrm{fg}}$ \\
\hline
\end{tabular}

Keterangan: Angka yang diikuti oleh huruf sama pada baris dan kolom yang sama tidak berbeda nyata pada taraf $5 \%$ uji jarak berganda Duncan

Remarks: Values followed by the same letter in the same row and column are not significantly different at the $5 \%$ level, according to Duncan's multiplerange test
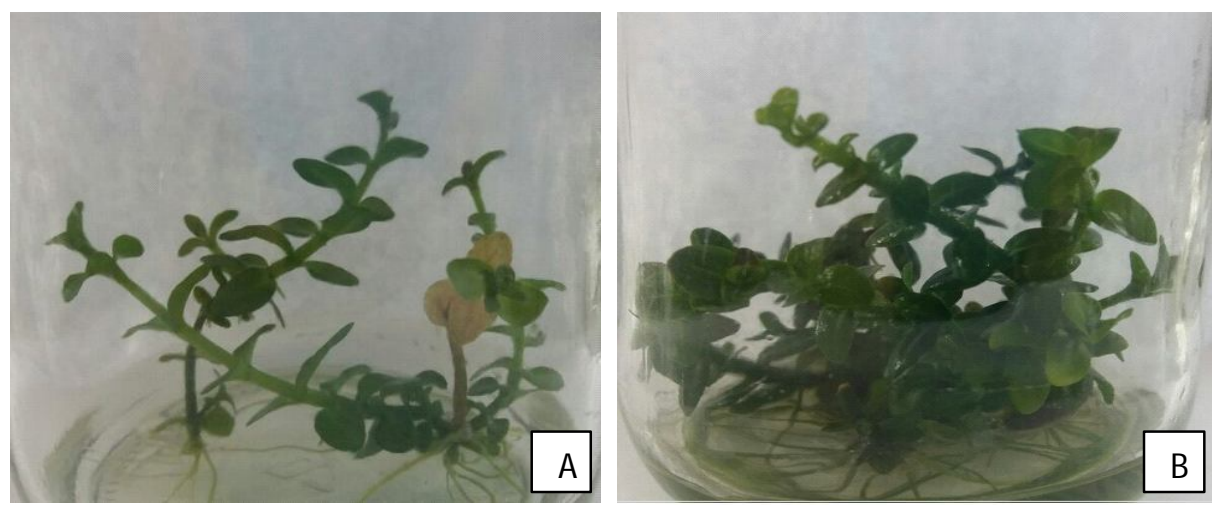

Gambar 3. Tunas yang dimultiplikasi pada media MS + thidiazuron 0,1 mg/L (A); tunas yang dimultiplikasi pada media $M S+B A 0,5+$ thidiazuron $0,1 \mathrm{mg} / \mathrm{L}(\mathrm{B})$.

Figure 3. Shoot multiplication in medium of $M S+$ thidiazuron $0.1 \mathrm{mg} / \mathrm{L}(\mathrm{A}) ; \mathrm{MS}+$ BA $0.5+$ thidiazuron $0.1 \mathrm{mg} / \mathrm{L}(\mathrm{B})$. 
Pemberian zat pengatur tumbuh BA dan thidiazuron secara bersamaan mampu meningkatkan kemampuan tunas untuk bermultiplikasi daripada perlakuan BA atau thidiazuron secara tunggal. Pada percobaan ini pemberian $\mathrm{BA}$ dan thidiazuron yang optimum adalah pada konsentrasi $0,5 \mathrm{mg} / \mathrm{L}$ BA dan 0,1 mg/L thidiazuron di mana rata-rata tunas yang dihasilkan adalah 32,4 tunas sedangkan jumlah daun adalah 137,6 daun (Gambar 3B) dan memberikan pengaruh yang berbeda nyata dari perlakuan lainnya. Parameter jumlah cukup penting untuk diamati karena dari ketiak daun dapat muncul tunas sehingga dapat meningkatkan faktor multiplikasi tunas. Hasil penelitian ini menunjukkan bahwa formulasi media terbaik untuk multiplikasi tunas adalah $\mathrm{MS}+0,5 \mathrm{mg} / \mathrm{LBA}+0,1 \mathrm{mg} / \mathrm{L}$ thidiazuron. Pengunaan thidiazuron pada media kultur pada konsentrasi relatif rendah lebih efektif bila dikombinasi dengan BA, akan tetapi apa bila konsentrasi BA dan thidiazuron relatif lebih tinggi cenderung akan menurunkan kemampuan tunas untuk bermultiplikasi. Hal ini juga terjadi pada tanaman yang memiliki khasiat obat seperti Kigelia pinnata, kemampuannya bermultiplikasi meningkat dengan pemberian thidiazuron 0,5 ìm dan bila konsentrasi terus ditingkatkan maka kemampuan tunas untuk bermultiplikasi menjadi menurun (Thomas \& Puthur, 2004). Hal ini karena sitokinin eksogen yang diberikan dalam konsentrasi berlebih akan dapat meningkatkan enzim sitokinin oksidase yang berperan memelihara keseimbangan sitokinin dalam sel tanaman dengan mengoksidasi kelebihan sitokinin bila tidak diperlukan sehingga akan menghambat pertumbuhan organ (Staden et al., 2008).

\section{Induksi Perakaran}

Memproduksi bibit memerlukan plantlet utuh yang memiliki batang, daun, dan akar; untuk itu, diperlukan formulasi yang tepat untuk induksi perakaran. Hasil yang diperoleh pada penelitian ini menunjukkan bahwa secara umum pemberian IBA dapat memicu terbentuknya akar pada kultur in vitro. Hasil analisis ANOVA menunjukkan bahwa perlakuan IBA memberikan pengaruh yang berbeda nyata terhadap jumlah dan panjang akar. Perlakuan IBA yang terbaik untuk induksi perakaran adalah pada konsentrasi 0,5 $\mathrm{mg} / \mathrm{L}$; di mana pada konsentrasi tersebut mampu menghasilkan akar sebanyak 2,9 dan rataan panjang akar 2,92 cm (Gambar 4 dan 5). IBA merupakan salah satu zat pengatur tumbuh jenis auksin yang umum digunakan untuk menginduksi perakaran tanaman secara in vitro. Hasil penelitian Bohidar et al. (2008) dengan menggunakan pelakuan IAA (Indole-3-acetic acid), IBA dan NAA (Naphthaleneacetic acid) pada konsentrasi 0,25-1 mg/L menunjukkan bahwa IBA memberikan respons tercepat dalam menginduksi panjang akar Ruta graveolens.

Peningkatan perlakuan konsentrasi IBA menjadi 1 $\mathrm{mg} / \mathrm{L}$ menurunkan kemampun tunas untuk membentuk akar; di samping itu, akar yang dihasilkan lebih pendek

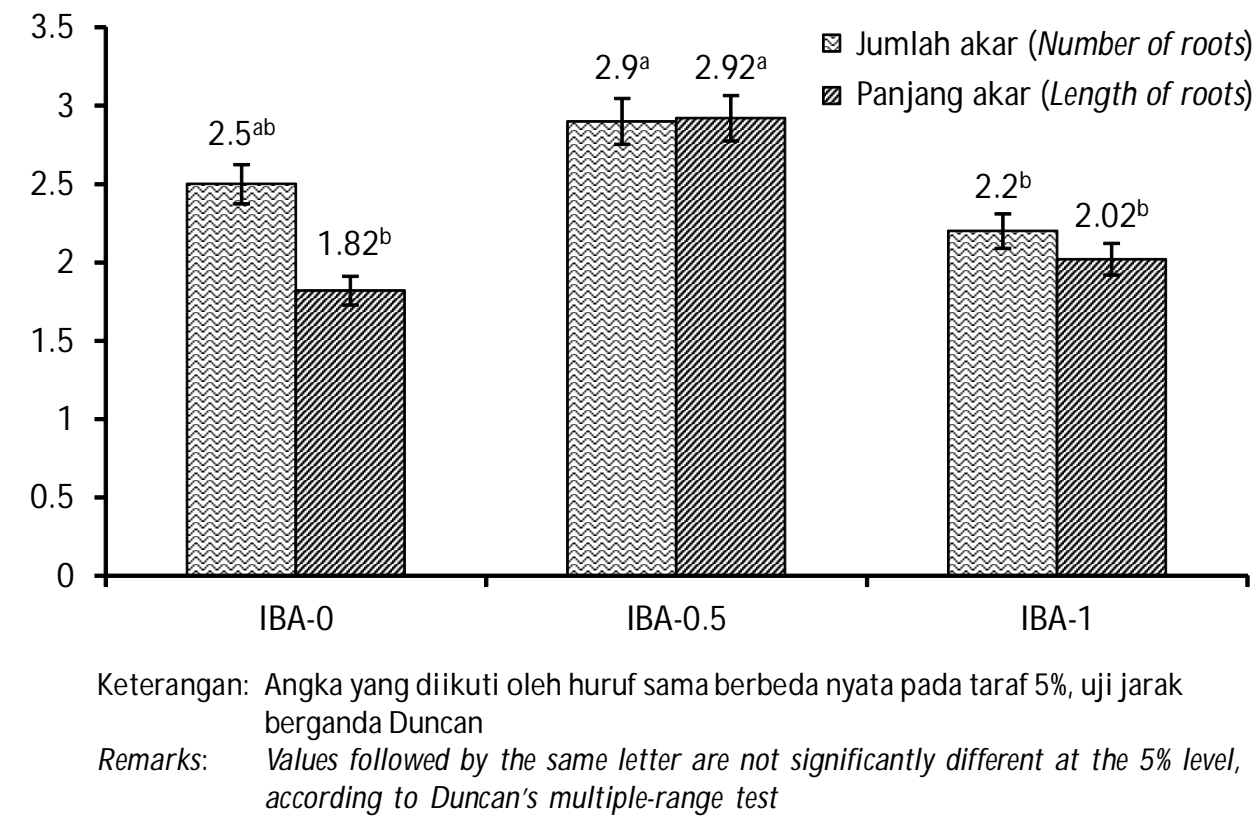

Gambar 4. Pengaruh konsentrasi IBA terhadap jumlah dan panjang akar pada eksplan Bacopa australis.

Figure 4. The influence of IBA concentration on the number and length of roots on Bacopa australis explant. 


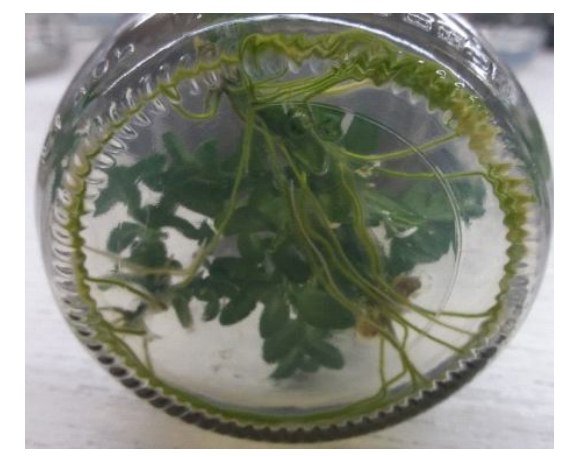

Gambar 5. Akar yang dihasilkan dari media MS + IBA 0,5 mg/L.

Figure 5. Root produced from MS + IBA medium $0.5 \mathrm{mg} / \mathrm{L}$.

yaitu rata-rata jumlah akar yang dihasilkan adalah 2,2 akar dengan rata-rata panjang akar $2,02 \mathrm{~cm}$. Penambahan auksin pada konsentrasi yang optimal pada media biakan dapat menginduksi pembentukan akar lebih baik, akan tetapi apabila konsentrasi yang diaplikasikan relatif tinggi cendrung akan menghambat pembentukan dan pertumbuhan akar tersebut (Srivastava, 2002; Davies, 2004). Aplikasi auksin eksogen dalam konsentrasi tinggi pada media kultur cenderung menstimulasi diferensiasi jaringan pembuluh dengan lebih cepat, sehingga akan meningkatkan jumlah dan ukuran jaringan.

\section{KESIMPULAN}

Formulasi media yang terbaik untuk induksi tunas Bacopa australis secara in vitro adalah MS + BA 0,3 mg/ L. Formulasi media yang optimal untuk multiplikasi tunas adalah $\mathrm{MS}+\mathrm{BA} 0,5 \mathrm{mg} / \mathrm{L}+$ thidiazuron $0,1 \mathrm{mg} /$ $L$ dan untuk induksi perakaran adalah MS + IBA 0,5 $\mathrm{mg} / \mathrm{L}$.

\section{UCAPAN TERIMA KASIH}

Terima kasih kepada Program Insentif Riset Inovasi Nasional (Insinas) tahun 2017-2018, Kementerian Riset Teknologi Dan Pendidikan Tinggi yang telah mendanai penelitian ini, melalu program Insinas Kemitraan.

\section{DAFTAR ACUAN}

Bohidar, S., Thirunavookkasasu, M., \& Ro, T.V. (2008). Effect of plant growth regulators on in vitro micropropagation of "Garden Rue" (Ruta graveolens L.). International Journal of Integrative Biology, IJIB(3), 36-43.

Bank Indonesia. (2008). Pola pembiayaan usaha kecil industri tanaman air. www.bi.go.id.

Chandran, C., Karthikeyan, K., \& Kulothungan, S. (2007). In vitro propagation of Withania somnifera (L.) Dunal. from shoot tip and nodal explants.
Journal of Scientific Transactions in Environment and Technovation, 1(1), 15-18.

Davies, P.J. (2004). The plant hormones: Their nature, occurrence, and functions. In Davies, P.J. (Ed.). Plant hormones biosynthesis, signal transduction, action!. London: Kluwer Academic Publisher, p. 135.

Dharishini, M.P., Balasubramanian, K., \& Radha, A. (2014). In Vitro micropropagation of Bacopa monnieri and detection of bacosides from secondary callus. Journal of Academia and Industrial Research, 3(5), 233-235.

Guo, B., Abbasi, B.H., Zeb, A., Xu, L.L., \& Wei, Y.H., (2011). Thiadiazuron: A multi-dimensional plant growth regulator. Afr. J. Biotechnol., 10, 8984-9000.

Hartati, S., Triana, E., Yunus, A., \& Susilowati, A. (2014). kajian sitokinin benzilaminopurin (BAP) terhadap organogenesis hasil persilangan Dendrobium merbelianum dengan Dendrobium liniale. El-Vivo, 2(2), 22-33.

http://tropica.com/fr/guide/r\%C3\%A9ussir-sonaquarium/engrais-et-co2/. Acces 1 Maret 2017.

Kapil, S.S. \& Sharma, V. (2014). In vitro propagation of Bacopa Monneri: An important medicinal plant. Int. J. Curr. Biotechnol., 2(1), 7-10.

Karyanti. (2017). Pengaruh beberapa jenis sitokinin pada multiplikasi tunas anggrek Vanda douglas secara in vitro. J. Bioteknol. Biosains Indonesia, 4(1), 36-42.

Khawar, K.M., Sevimay, C.S., \& Yuzbasioglu, E. (2003). Adventitious shoot regeneration from different explant of wild lentil (Lens Culinaris Subsp. Orientalis). University of Ankara, Ankara. Turkey.

Murashige, T. \& Skoog, F. (1962). A revised for rapid growth and bioassays with tobacco tissue cultures. Physiol. Plant, 15, 473-497.

Nugraha, M.F.I., Yunita, R., Lestari, E.G., \& Ardi, I. (2017). Pembentukan mother plant Bacopa austra- 
lis secara in vitro pada berbagai dosis zat pengatur tumbuh dan media aklimatisasi. Media Akuakultur, 12(2), 85-94.

Pandiyan, P. \& Selvaraj, T. (2012). In vitro multiplication of Bacopa monnieri (L.) Pennell from shoot tip and nodal explants. Journal of Agricultural Technology, 8(3), 1099-1108.

Santos, C.V., Brito, G., Pinto, G., Fosiseca, M., \& Henrique. (2003). In vitro plantlet regeneration of Olea eruopaea spp. maredenis. Scientia Hort., 97, 83-87.

Srivastava, L.M. (2002). Plant growth and development, hormon and environment. London: Academic Press, 772 pp.

Staden, J., Van, E., Zazimalova, E., \& George, E.F. (2008). Plant growth regulator II: Cytokinin, their analogues and antagonists. In George, E.F., Hall, M.A., \& de Klerk, G.J. (Eds.). Plant propagation by tissue culture Vol. I. The background. Springer. Dordrecht, p. 205-226.

Syahid, S.F. \& Kristina, N.N. (2008). Multiplikasi tunas, ak limatisasi dan analisis mutu simplisia daun encok (Plumbago zeylanica L.) asal kultur in vitro periode panjang. Bul. Littro., XIX(2), 117-128.

Thomas, T.D. \& Puthur, J.T. (2004). Thidiazuron induced high frequency shoot organogenesis in callus from Kigelia pinnata L. Bot. Bull. Acad. Sin., 45, 307-313.
Thomas, T.D. \& Shankar, S. (2009). Multiple shoot induction and callus regeneration in Sarcostemma brevistigma Wight \& Arnott, a rare medicinal plant. Plant Biotechnologi Report, 3(36), 7-12.

Tuhuteru, S., Hehanussa, M.L., \& Raharjo, S.H.T. (2012). Pertumbuhan dan perkembangan anggrek Dendrobium anosmum pada media kultur in vitro dengan beberapa konsentrasi air kelapa. Agrologia, 1, 1-12.

Vijayakumar, M., Vijayakumar, R., \& Stephen, R. (2010). In vitro propagation of Bacopa monnieri L. - a multipurpose medicinal plant. Indian Journal of Science and Technology, 3(7), 781-786.

Yunita, R. \& Lestari, E.G. (2008). Perbanyakan tanaman Artemisia annua secara in vitro. Jurnal Agro Biogen, 4(1), 41-44.

Yunita, R. \& Lestari, E.G. (2011). Perbanyakan tanaman pulai pandak (Rauw olfia serpentina L.) dengan teknik kultur jaringan. Jurnal Natur Indonesia, 14(1), 6872.

Yunita, R., Mariska, I., \& Tumilisar, C. (2012). Perbanyakan tanaman jambu mete (Anacardium occidentale L.) melalui jalur organogenesis. Jurnal Agro Biogen, 8(3), 113-119.

Zulkarnain. (2011). Kultur jaringan tanaman, solusi perbanyakan tanaman budi daya. Jakarta: PT Bumi Aksara, $272 \mathrm{hlm}$. 